\title{
A review of the characterization and evaluation of permeable friction course mixtures
}

\author{
Revisión de la caracterización y evaluación de mezclas drenantes
}

\author{
Allex E. Alvarez-Lugo ${ }^{1} \quad$ Oscar J. Reyes-Ortiz ${ }^{2} \quad$ Rodrigo Miró ${ }^{3}$ \\ Recibido 2 de abril de 2012, aceptado 19 de mayo de 2014 \\ Received: April 2, $2012 \quad$ Accepted: May 19, 2014
}

\begin{abstract}
Permeable friction course (PFC) mixtures are a special type of hot mix asphalt (HMA) mixtures characterized by high total air voids (AV) content values to provide high permeability and noise reduction effectiveness, while high surface texture conditions can be ensured. Recent advancements in materials and HMA mixture evaluation led to increase the use of PFC mixtures over the last two decades as an alternative to improve highway safety and noise reduction. However, these developments on PFC mixtures generate the need for a comprehensive review to facilitate corresponding practical implementation. Consequently, the main objective of this paper is to provide a summary of research findings on PFC mixtures to improve the conception, design, and use of these HMA mixtures. In this context, the paper includes aspects related to advantages and limitations, volumetric properties, structural life, mixture distresses, and functionality of PFC mixtures. The aspects summarized provide a baseline for improvement of the current design and conception of PFC mixtures and offer guidelines for some future research developments.
\end{abstract}

Keywords: Permeable friction course (PFC), mix design, hot mix asphalt (HMA), noise reductionpavements, drainable pavements.

\section{RESUMEN}

Las mezclas drenantes son un tipo especial de mezclas asfálticas caracterizadas por un alto contenido total de vacíos, que proporcionan alta permeabilidad y capacidad de reducción de los niveles de ruido, mientras se garantizan altos valores de textura superficial. Avances recientes en materiales y evaluación de mezclas asfálticas conllevaron al incremento del uso de mezclas drenantes en las dos últimas décadas como alternativa para mejorar la seguridad vial y controlar los niveles de ruido. Sin embargo, estos desarrollos en mezclas drenantes generan la necesidad de una revisión completa para facilitar la implementación práctica correspondiente. Consecuentemente, el objetivo principal de este artículo es proporcionar un estado del arte de resultados de investigación sobre mezclas drenantes para mejorar la concepción, diseño y el uso de estas mezclas asfálticas. En este contexto, el artículo incluye aspectos relacionados con las ventajas y limitaciones, propiedades volumétricas, vida estructural, patologías de la mezcla y funcionalidad de las mezclas drenantes. Los aspectos resumidos proporcionan un punto de partida para el mejoramiento de la concepción y diseño actual de las mezclas drenantes y ofrecen una guía para futuros desarrollos en investigación.

Palabras clave: Mezcla drenante, diseño de mezcla, mezcla asfáltica en caliente, pavimentos sonorreductores, pavimentos permeables.

1 Departamento de Ingeniería Civil. Universidad del Magdalena. Colombia. Código postal: 470004. Teléfono: +5754301292 . E-mail: allexalvarez@yahoo.com

2 Departamento de Ingeniería Civil. Universidad Militar Nueva Granada. Colombia. Código postal: 11001000. Teléfono: +5717480333. E-mail: oscar.reyes@ unimilitar.edu.co

3 Departamento de Infraestructura del Transporte y del Territorio. Universidad Politécnica de Cataluña. Barcelona, España. Código postal: 08034. Teléfono: +934017085. E-mail: r.miro@upc.edu 


\section{INTRODUCTION}

Permeable friction course (PFC) mixtures are also termed new generation open-graded friction course (NG-OGFC) mixtures-to differentiate them from the conventional open-graded friction course (OGFC) mixtures used up to 2000 approximately-in the United States of America. In Europe similar mixtures are named as porous asphalt. These special hot mix asphalt (HMA) mixtures are usually used as thin (i.e., approximately 30 to $50 \mathrm{~mm}$ in thickness [1-3]) wearing surface layers.

PFC mixtures are characterized by higher total air voids (AV) content-on the order of 18 to $25 \%$-and bigger $\mathrm{AV}$ as compared to conventional densegraded HMA [4]. PFC mixtures also have higher total AV content values and are placed in thicker layers than the conventional OGFC mixtures. These characteristics are obtained by means of the open aggregate gradation used in PFC mixtures. Figure 1 shows a comparison-grayscale image with the AV represented in black color-of the internal structure of a typical PFC mixture and a dense-graded HMA mixture.

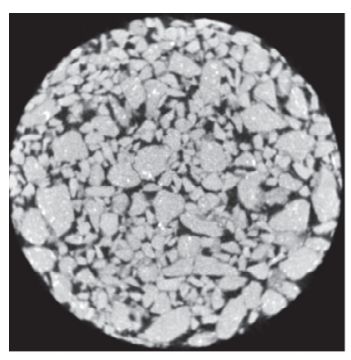

(a)

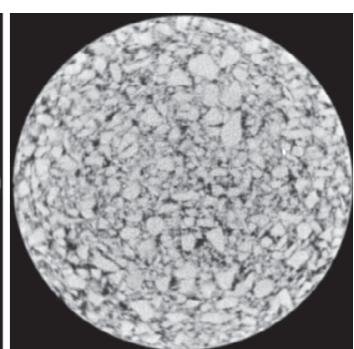

(b)
Figure 1. Comparison of the internal structure of a PFC mixture (a) and a dense-graded HMA mixture (b).

As a consequence of the particular internal structure, the connected AV content (i.e., proportion of AV in the mixture that are accessible to water) in PFC mixtures is also higher than in conventional densegraded HMA. Previous research reported ratios of connected $\mathrm{AV}$ content to total $\mathrm{AV}$ content ranging from 65 to $100 \%$ in PFC mixtures [5]. The high connected AV content and the layer thickness (30 to $50 \mathrm{~mm}$ ) ensures noise reduction capacity and high permeability to the PFC mixtures, while high surface texture is also obtained [6-7]. In addition, the mixture durability and stability (required to prevent the mixture disintegration through progressive loss of aggregates starting at the pavement surface-a phenomenon known as raveling-) is based on the full stone-on-stone contact obtained by the coarse aggregate fraction of the compacted mixture and proper mixture cohesion provided by the asphalt.

Advantages of the PFC mixtures-as compared to conventional dense-graded HMA mixtures-include reduction of highway noise levels [8-9], water splash and spray $[8,10]$ and hydroplaning [10], and wet skidding risk [11]. The advantages also include improvement of pavement markings visibility in wet weather [12], better, or at least comparable, surface friction [6, 13-14], and cleaner runoff water [15]. As a consequence, reduction of accidents has been reported as a benefit from the PFC mixtures implementation [16]. However, previous research [17] concluded that in terms of road safety, the use of porous asphalt mixtures did not show a clear effect, since the findings in this matter are inconclusive.

Compared to the dense-graded HMA mixtures, some limitations of the PFC mixtures are related to: $(i)$ increased (i.e., immediately after construction) initial asphalt film thickness that can reduce the surface friction [18], (ii) tendency to accumulate black ice and freeze faster and longer [19], (iii) winter maintenance (i.e., in freezing conditions) problems [19], and (iv) relatively high construction cost [20]. In addition, limited structural capacity [21] and reduced functional life (i.e., loss of permeability and noise reduction capacity due to AV clogging) [22] had been indicated as disadvantages of the PFC mixtures. However, several factors (e.g., vehicle speed, road environment, mixture gradation, etc.) are related to the loss of functionality, and the typical PFC mixture functional life reported in the literature ranges between 3 and 9 years [23].

PFC mixtures (termed differently in the past) have been used in the United States since 1950 approximately [24] and in Europe since the end of the 1970's. During the past two decades, however, several advances in materials and evaluation of asphalt mixtures led to improvements in the mix design and construction of PFC mixtures, which allowed for enhanced durability and functionality. The mix design of PFC mixtures is not yet a unified practice, and different agencies around the 
world have structured diverse design approaches. In fact, different mixture characterization aspects can still be improved, and, therefore, there can be opportunities for enhancement of the different mix design approaches currently proposed.

Relevant works in this direction include the mix design methods proposed for OGFC mixtures in 1974 [25], NG-OGFC mixtures in 1999 [26] and OGFC mixtures in 2002 [27], the refinement of NGOGFC mix design presented in 2003 [28] and the mix design method proposed for PFC mixtures in 2011 [29]. In addition, Spain, for example, structured a design method based on the Cantabro test since 1987 [3]. This test has also been adopted for design of porous asphalt mixtures and PFC mixtures in other countries [23, 30]. Previous research [6, 23, 31] summarized some of these methods, as well as other design approaches and corresponding specifications adopted by several agencies in different countries around the world.

As a consequence of the aforementioned improvements, the use of PFC mixtures increased over the last two decades as an alternative to improve highway safety and control the highway noise levels. Given these recent advances, there is a need for a comprehensive review of these modifications.

Consequently, the main objective of this paper is to provide a summary of research findings on PFC mixtures to improve the conception, design, and use of these mixtures. After this introductory section, the paper presents a review of aspects related to volumetric properties, structural life, mixture distresses, and functionality of PFC mixtures. The paper ends with a section on conclusions and recommendations.

\section{VOLUMETRIC PROPERTIES}

Evaluation of volumetric properties of PFC mixtures basically includes computation of the total AV content and more recently the connected AV content. Final recommendations on the methods to compute the inputs involved in the $\mathrm{AV}$ content computation for PFC mixtures is still debatable and different research led to diverse recommendations.

Previous literature [32] provide a summary of the methods available to compute the total $\mathrm{AV}$ content in HMA mixtures. In addition, previous research $[13,33]$ concluded that the conventional test method (AASHTO T 166; based on the specimen saturated surface-dry weight) was not applicable for computing the bulk specific gravity of the compacted PFC mixture, $G_{m b}$, and subsequent calculation of the total AV content.

Among the alternative methods proposed, research conducted back in 1987 recommended dimensional analysis [3]. More recent works [5, 34] also recommended dimensional analysis over the vacuum method [35] to compute $G_{m b}$. However, alternative research $[28,36-37]$ recommended the vacuum method.

In the dimensional analysis, the mixture total volume is computed by assuming the mixture specimen as a regular cylinder. The vacuum method recurs to the buoyancy principle to compute the total volume of the mixture specimen-once the specimen has been wrapped in a particular plastic bag sealed under vacuum-. Thus, the dimensional analysis and the vacuum method basically differ in the proportion of surface AV included in the computation of the total volume of the specimen. The former, fully includes the surface $\mathrm{AV}$, while the vacuum method partially includes them.

In terms of the computation of the theoretical maximum specific gravity of the mixture, $G_{m m}$, previous research [34] recommended using calculated $G_{m m}$ values determined based on $G_{m m}$ measurements conducted on PFC mixtures fabricated at low asphalt contents (i.e., in the range of 3.5 to $4.5 \%$ ). This procedure is an alternative to the conventional determination of $G_{m m}$-based on weight and indirect volume measurements on mixtures fabricated at the design asphalt content, which is typically higher than $4.5 \%$ in PFC mixtures-.

The most commonly used methods for estimation of the connected AV content (which can be adopted as a surrogate of the total AV content) correspond to the vacuum method [5, 34-35] and dimensional analysis [5, 34]. The vacuum method recurs to the buoyancy principle to compute the total volume of the specimen and then, to immersion of the specimen to determine its saturated weight. The specimen saturation process is conducted after cutting, under 
water, the vacuum-sealed bag used to compute the specimen total volume. On the other hand, in the dimensional analysis the specimen is adopted as a regular cylinder to compute its total volume and its saturated weight is measured after simple immersion (without previous saturation, vacuum, or shacking). However, additional research was suggested to further validate the process to measure the specimen saturated weight in the dimensional method [5].

\section{MIXTURE STRUCTURAL LIFE}

The stability and durability-structural life-of PFC mixtures relies on the asphalt binder properties (i.e., rheological properties and quality of adhesion at the asphalt-aggregate interface, or more specifically at the mastic-aggregate interface) and the full stoneon-stone contact achieved by the coarse aggregate fraction in the compacted mixture.

Previous research consistently substantiates that fabrication of PFC mixtures requires the use of modified asphalts [26, 38-40]. In Texas, for example, PFC mixtures are fabricated using high stiffness asphalts including polymer modified (PM) asphalts (i.e., performance graded (PG) as PG 76-XX) and asphalt rubber (AR) asphalts [41]. These AR asphalts contain a minimum of $15 \%$-by weight of virgin asphalt-of crumb rubber [41], and the mixtures fabricated using PM asphalts include lime to minimize moisture damage and fibers to prevent asphalt draindown issues. Previous literature concluded that PFC mixtures fabricated with PM asphalts and inclusion of lime exhibited improved laboratory performance as compared to those fabricated with PM asphalts [42-43].

Previous research [27] also recommended stiff binders for PFC mixtures (i.e., two PG grades stiffer than the PG conventionally used for the local climatic conditions). This recommendation is coincident with that included by ASTM for the design of PFC mixtures [44]. In addition, previous studies [45] reported fabrication of PFC mixtures using low penetration-polymer modified-asphalts (i.e., $45(1 / 10 \mathrm{~mm})$ in Japan [45], and $48(1 / 10 \mathrm{~mm})$ in Taiwan [18]). Several agencies also specified asphalts with penetration values in the range of 50 to $100(1 / 10 \mathrm{~mm})$ [23]. However, the use of soft binders $-100 / 150$ or $160 / 220(1 / 10 \mathrm{~mm})$ was specified in England for fabrication of porous asphalt [46].

This contradiction in the design criteria can be related to the asphalt content specified. In Texas, where high asphalt contents are used (e.g., 5.5-7\% for PM asphalts), the main durability problems can be related to asphalt draindown instead of asphalt embrittlement and resistance to mixture disintegration by abrasion. Thus, the low penetration asphalts can exhibit a better response than the high penetration asphalts. On the other hand, in the European and Japanese mixtures the asphalt content is lower (i.e., 4-6\%) as compared to the mixtures produced in Texas. In this case, the main durability problems are not related to asphalt draindown, but to loss of aggregate particles by abrasion and impact (i.e., raveling). Therefore, high penetration asphalts, and specially the modified asphalts, can exhibit proper durability response due to their ductility and toughness.

The quality of adhesion at the asphalt-aggregate interfaces of typical material combinations used in Texas PFC mixtures was recently evaluated using surface free energy (SFE) measurements and energy indices [47]. Corresponding research concluded that PM- and AR-asphalts can offer similar quality of adhesion in both dry condition and wet condition (i.e., similar resistance to fracture and moisture damage). However, differences in the performance of PFC mixtures fabricated using these asphalts should be expected-and were previously identified in terms of fatigue resistance [48], for example-, based on the divergences in the asphalt rheological properties, mixture gradation, asphalt content, and inclusion of additives as previously indicated. Computation of energy indices, based on SFE measurements, can help to optimize the aggregate-asphalt-filler combinations for future fabrication of PFC mixtures [49].

Stone-on-stone contact can be evaluated in PFC mixtures based on the voids in the coarse aggregate method-or VCA method-suggested in 1999 [26]. This method was initially validated [50] using image analysis, and recommendations were suggested [51] in 2010 to better ensure the achievement of a fully developed stone-on-stone contact condition. Evaluation of stone-on-stone contact is critical to 
ensure the durability of PFC mixtures and should be required for mix design.

In addition, the aggregate gradation affects the internal arrangement of stone-on-stone contact-and consequently the $\mathrm{AV}$ characteristics-developed in the PFC mixture. Thus, the aggregate gradation has a significant effect on the PFC mixture response and performance [1, 52-53] including the mixture resistance to permanent deformation and disintegration, macrotexture, and permeability.

Therefore, the aggregate gradation should be evaluated as a function of the parameters to optimize (e.g., permeability, noise reduction capacity, and/or surface texture) for a specific application of a PFC mixture. For comparison purposes, Figure 2 presents aggregate gradations curves (i.e., mean values of corresponding aggregate gradation bands) specified for PFC mixtures by different agencies around the world. As shown in the figure, different gradations are specified for the Texas PFC mixtures fabricated using AR- and PM-asphalts to allow targeting similar total AV content values with higher contents of AR.

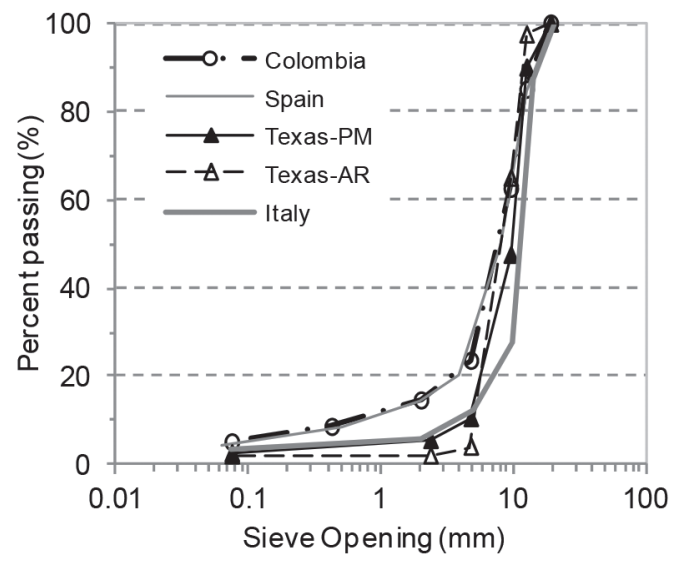

Figure 2. Comparison of mean aggregate gradation curves specified for PFC mixtures.

Previous research $[1,54]$ recommended to keep a minimum amount of filler content, ranging between 3 and $4.5 \%$, to provide cohesion and reduce the mixture susceptibility to raveling. However, some current specifications (e.g., [41]) allow filler contents as low as $0 \%$ for mixtures fabricated with AR asphalts (or AR-PFC mixtures) and $1 \%$ for those constructed using PM asphalts (or PM-PFC mixtures). Evaluation of the minimum content-and type of filler-to be used for fabrication of PFC mixtures still requires assessment given its effect on the thermodynamic response of the asphalt-aggregate combinations [55] and the macroscopic response of the mixture.

\section{MIXTURE DISTRESSES AND ASPECTS RELATED}

Conventional fatigue cracking (i.e., bottom-up or top-down) and permanent deformation (or rutting) have not been typically considered the main distresses affecting the durability and functionality of PFC mixtures [40]. Consequently, a small proportion of the research efforts have been directed toward corresponding laboratory testing and field evaluation. However, raveling (exemplified in Figure 3) has been historically reported as the main distress causing durability problems in PFC mixtures [6, 38-40]. Therefore, increasing research has been dedicated to assess the laboratory mixture resistance to disintegration to minimize raveling issues.

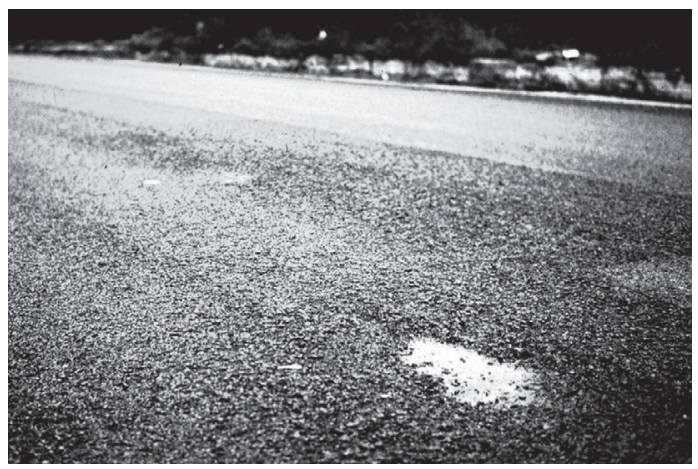

Figure 3. Raveling affecting a porous asphalt field section.

Diverse laboratory tests have been proposed to characterize the durability of PFC mixtures. A comprehensive list of these tests can be found in previous literature [56]. However, the test most commonly used to assess the resistance to disintegration of PFC mixtures is the Cantabro, which was developed between 1978 and 1980 [54, 57], and standardized in Spain in 1986 [58]. This test has been used for mix design [59] and in numerous research on PFC mixtures around the world.

Main causes of raveling can be related to materials selection and response as well as mix design including: (i) moisture damage (i.e., stripping) in the PFC mixture or in the underneath HMA layer 
[11, 13, 60], (ii) asphalt oxidative aging [45], (iii) limited asphalt film thickness [11], (iv) asphalt draindown [60], and ( $v$ ) aggregate degradation during compaction. Raveling can also be associated with inadequate construction practices that include: $(i)$ lack or poor tack coat underneath the PFC mixture, (ii) improper mixture compaction [61], and (iii) aggregate and temperature segregation [60]. Other causes of raveling include the reduction of asphalt stiffness due to oil and fuel drippings in accidents zones and parking areas [23].

As discussed in previous literature [60], moisture damage (illustrated in Figure 4) can lead to loss of adhesion at the asphalt-asphalt interfaces (cohesive failure [62]) and asphalt-aggregate interfaces (adhesive failure [49, 63]) and can become the primary reason for raveling failure in PFC mixtures. A similar discussion, without integrating the moisture damage as a cause of raveling, is stated in published literature [64].

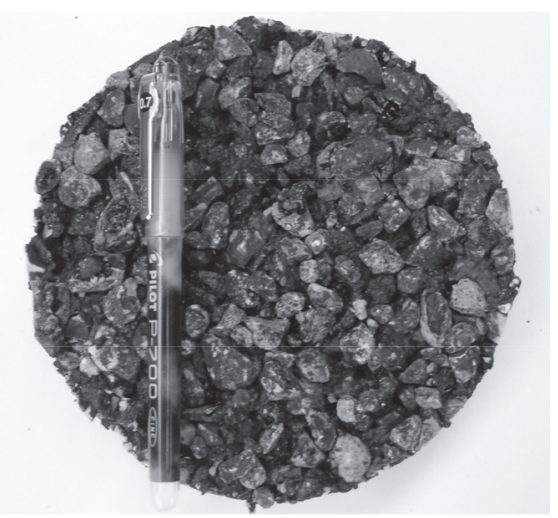

Figure 4. Moisture damage distress in a PFC mixture.

Computation of energy indices, based on SFE measurements, can be applied to optimize the resistance to moisture damage and fracture of the asphalt-asphalt and asphalt-aggregate interfaces of PFC mixtures. This application is documented elsewhere [65]. The analysis of the moisture effect on the loss of strength and the susceptibility to abrasion loss (i.e., raveling) was introduced since the development of the porous asphalt mixtures in Spain. Corresponding evaluation was initially proposed in terms of the Cantabro test conducted on moisture conditioned specimens [66], which is still used in several mix design procedures specified by different agencies.
The failure at the interfaces of the mixture constituents can also be attributed to a fatigue loading process, which is favored by excessive asphalt aging, triggered at low temperature conditions, and can further develop if moisture damage is degrading the interfaces. Under the traffic action, this process can lead to the loss of aggregates at the mixture surface and prompt the raveling distress mechanism.

Asphalt oxidative aging, favored by the exposure to ultraviolet sunlight $[60,67]$ in the open AV structure of the PFC mixtures, can also cause loss of adhesion at the asphalt-aggregate interfaces [45, 68-69] and increase the asphalt stiffness (i.e., complex modulus) due to structural and chemical changes [70-71]. Therefore, asphalt aging reduces the mixture capacity to withstand the traffic and environmental stress and strain impositions.

The optimum asphalt content specified, for example in Texas, for AR-PFC mixtures and PM-PFC mixtures are, respectively, in the range of 5.5 to $7 \%$ and 8 to $10 \%$ [41]. In general, the asphalt contents specified for PFC mixtures are higher than those of conventional dense-graded HMA [41, 68]. However, as previously discussed, certain agencies (e.g., in Spain, Denmark, Belgium, Australia [23], and Colombia [72]) specify similar asphalt contents for both types of mixture.

The high asphalt content in the Texas PFC mixtures is a design specification to ensure thick asphalt films coating the aggregate as a way to minimize asphalt aging and reduce the probability of raveling [56]. However, additional research is required to support this hypothesis by evaluating the aging rate in PFC mixtures.

Asphalt draindown-a particular segregation phenomenon-can lead to raveling after generating irregular vertical distributions of the asphalt films in the PFC mixture [11]. In addition, accumulation of asphalt at the PFC layer bottom can be detrimental in terms of permeability and susceptibility for rutting and flushing [11]. Currently, prevention of draindown issues in PM-PFC mixtures is successfully addressed by addition of different types of fibers $[68,69,73$, 74]. However, fabrication of the AR-PFC mixtures with addition of fibers is not a common practice. A recent study [75] also supported the successful laboratory production of PFC mixtures using warm 
mix asphalt (WMA) additives (i.e., Evotherm ${ }^{\mathrm{TM}}$ WMA and foaming WMA) without requiring the inclusion of fibers for draindown prevention.

Aggregate degradation during compaction can also be a factor generating accelerated damage (e.g., moisture damage), since it creates fractured particles with deficient or inexistent asphalt coating in the compacted PFC mixture, which affects the initial asphalt coating conditions achieved during the plant production stage. This kind of degradation in the aggregates was reported in previous research [28], although quantification of its actual effect on the mixture durability is limited at this point. Proper selection of the aggregates can minimize this detrimental phenomenon.

Placement of a proper tack coat is important to bond the PFC mixture to the underlying surface. The tack coat can also seal the structural layers surface to minimize the detrimental effects of water intrusion [76]. Recommendations from different agencies for the tack coat were previously summarized [24] and later [77] additional practical recommendations to minimize the possibility of moisture damage, after placing a PFC mixture, due to saturation of the underlying HMA layers were suggested.

Improper field compaction can lead to PFC mixtures susceptible to raveling $[61,78]$ due to partial development of stone-on-stone contact in the coarse aggregate fraction. However, current practice lacks proper field compaction controls [61], although previous studies analyzed the measurement of field water flow values (i.e., time to discharge a given water volume using a variable charge outflow meter) for a combined evaluation of compaction and drainability [79]. A particular example of this approach was discussed [1] using the LCS drainometer developed in Spain $[3,80]$ to control both the construction of PFC mixtures and the changes in their permeability along their functional life period.

In addition, the field compaction control of PFC mixtures based on evaluation of road cores showed limitations [81]. Therefore, alternative techniques are still required to determine the $\mathrm{AV}$ content and compaction quality in terms of vertical and horizontal uniformity. The Ground Penetrating Radar (GPR), for example, can constitute an efficient alternative to be explored for this specific application.

Aggregate- and temperature-segregation can lead to irregular compaction patterns-heterogeneous mixture internal structure that can contain unusually high AV contents-, which make the PFC mixtures prone to raveling and permanent deformation [60-61].

Maintenance of PFC mixtures is not conducted as in dense-graded HMA mixtures, and no major maintenance activities are reported as conventionally used for PFC mixtures [6, 23]. However, preventive surface maintenance has been performed by applying fog seals $[6,82]$, although this is not a generalized maintenance practice as it can lead to reduction of the AV size and AV connectivity. In addition, there is limited quantitative information available on the benefits of fog seals to extend the service life of PFC mixtures [83]. Distressed PFC mixtures have been treated with seal coats, or chip seals, when the functional properties are already discharged $[6,84]$.

In addition, winter maintenance for PFC mixtures requires particular approaches, since these mixtures are more prone to black ice formation as well as more frequent and earlier frost as compared to dense-graded HMA $[27,78]$. In particular, the winter maintenance of PFC mixtures include more frequent and higher rates of deicing agent application [12, 85]. Spreading of sand is not recommended as it can cause premature AV clogging [19] with loss of functionality.

In terms of preventing the loss of functionality due to progressive AV clogging, some European and Asian agencies support the AV cleaning using special equipment $[22,86]$. In the United States, however, this is not a common practice [23].

\section{MIXTURE FUNCTIONALITY}

High permeability, noise reduction effectiveness, and high skid resistance-as compared to densegraded HMA-are the core aspects related to the functionality of PFC mixtures and ensured several of their advantages over dense-graded HMA mixtures. However, most of the PFC mix design procedures currently implemented do not include verification of these aspects [31]. 
Previous research $[52,79]$ recommended verification of permeability as part of the mix design procedure as well as the field construction control. Corresponding implementation is possible based on the laboratory and field devices currently available, which were previously summarized [87]. Figure 5 shows one of these field devices used in Europe (i.e., LCS outflow meter [88]).

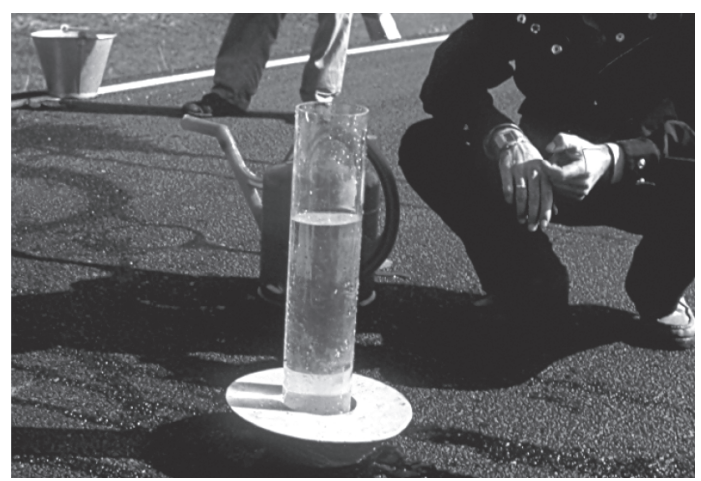

Figure 5. LCS variable charge outflow meter.

However, as indicated in published literature [87] there is still a need for unification of the devices used to measure the permeability coefficient (or permeability), since measurement comparisons are cumbersome at this point. The same research [87] also suggested measuring the permeability of PFC mixtures using smaller hydraulic heads than those currently specified in the European standard [89].

Unification of the compaction-and ultimately unification of the mixture internal structure-of the laboratory and field specimens used for permeability measurements is also required. This aspect was identified as significant to explain the differences in permeability reported for laboratory- and fieldcompacted PFC mixtures [79, 87]. These differences can also limit the evaluation of other functionality parameters for design, quality control, and modeling of the PFC mixtures.

The noise reduction effectiveness of PFC mixtures (and equivalent porous asphalt) as compared to surface layers composed by dense-graded HMA, SMA, and hydraulic concrete has been recognized in studies developed since the 1980's [90-93]. In addition, extensive research on this aspect has been conducted during the last decade as previously summarized [94].
Previous publications [93-95] also described different techniques and approaches available for measurement of highway noise levels. These techniques can be sorted in: $(i)$ near-field methods-including the onboard sound intensity (OBSI) method and close-proximity (CPX) method, and (ii) wayside methods-including the controlled pass-by (CPB) method and statistical pass-by (SPB) method [93, 95].

Using these devices, numerous studies, which were previously summarized [56, 94], identified the effect of different factors on the pavement noise level and can provide the basis to optimize the noise reduction effectiveness of PFC mixtures. As reported in previous research [94], these factors can include: $(i)$ a reduction in pavement roughness and texture, (ii) small nominal aggregate size and fine aggregate gradation, (iii) high AV content, and (iv) the use of AR. A reduction in the aggregate size of porous asphalt mixtures can also lead to a reduction of rolling resistance, leading to energy savings on the order of 2 to $2.5 \%$ [96].

Previous literature [94] summarized the research related to the evaluation of highway safety based on the use of PFC mixtures. The same report [94] also outlined the main techniques applied to measure the PFC mixture skid resistance (locked wheelregularly used in previous studies [94]-, sideway force, fixed slip, and variable slip) as well as the factors affecting it for future optimization of this functionality parameter. These factors include: $(i)$ high mixture texture, (ii), high aggregate texture, and (iii) use of AR.

\section{CONCLUSIONS AND RECOMMENDATIONS}

Although the use of PFC mixtures increased in the last decade, there is still a need for advancing in the analysis of different aspects related to mix design and evaluation for their full implementation. Consequently, this paper provides a review on aspects related to the characterization and evaluation of PFC mixtures including volumetric properties, structural life, mixture distresses, and functionality. Based on the review conducted, the following conclusions are offered:

- PFC mixtures constitute a proved alternative over the dense-graded HMA mixtures to improve 
highway safety, especially for driving during wet conditions.

- However, PFC mixtures are a special type of HMA mixture that require high quality materials and specific construction controls to ensure their structural life and functionality, and additional research is still required to optimize the mixture response and performance. For example, the evaluation of asphalt aging, aggregate degradation, compaction control, and maintenance needs (e.g., for minimization of AV clogging effects) require further assessment to fully validate the current design and construction approaches.

- Evaluation of the volumetric properties constitutes the core of the current PFC mix design. Although substantial progress has been achieved in this evaluation, there is still a need for unification of the measurement methods to determine the $G_{m m}$ and $G_{m b}$. Additional research should also focus on the field computation of the total AV content-in terms of both content and uniformity-or a surrogate parameter to better assess the compaction results.

- Although alternative tests have been proposed as surrogates, at present, the assessment of mixture durability (i.e., mixture resistance to disintegration) is mostly conducted based on the Cantabro test. This test allows for both assessment of the optimum asphalt content and mixture quality control.

- Evaluation of the aspects directly related to the functionality of PFC mixtures (i.e., permeability, noise reduction capacity, and skid resistance) should be included as part of the mix design process, since PFC mixtures with a broad range of functional responses can be produced depending on the design parameters selected (e.g., aggregate gradation). Overall, an standardized mix design method is still required to further promote the use of PFC mixtures based on optimum performance.

\section{DISCLAIMER}

The contents of this paper do not necessarily reflect the official policies of any agency. This paper does not constitute a standard, specification, nor is it intended for design or construction. Trade names were used solely for information and not for product endorsement.

\section{ACKNOWLEDGEMENTS}

The first author, as Associate Professor of the Universidad del Magdalena (Colombia), expresses special thanks to this institution and to the Fundación Carolina for the support received to successfully develop a research internship at the Universitat Politècnica de Catalunya and complete this work. The second author, as professor of the Universidad Militar Nueva Granada, thanks the Vice-rectory of Research for the support received-through the project IMP-ING-1575-to complete this paper.

\section{REFERENCES}

[1] A.R. Ruiz, R. Alberola, F.E. Pérez and B. Sánchez. "Porous Asphalt Mixtures in Spain". Transportation Research Record. Vol. 1265, pp. 87-94. 1990.

[2] R.J. Charbeneau, J.B. Klenzendorf and M.E. Barrett. "Methodology for Determining Laboratory and In Situ Hydraulic Conductivity of Asphalt Permeable Friction Course". Journal of Hydraulic Engineering. Vol. 137, pp. 15-22. 2011.

[3] Ministerio de Obras Públicas y Urbanismo-España. "Mezclas Bituminosas Porosas-MOPU". Madrid, España. 1987.

[4] A.E. Alvarez, J.S. Carvajal and L. Walubita. "Comparison of the air voids characteristics of different hot mix asphalt (HMA) mixture types”. Ingeniare. Revista chilena de ingeniería. Vol. $22 \mathrm{~N}^{\circ}$ 1, pp. 74-87. 2014.

[5] A.E. Alvarez, A. Epps Martin and C. Estakhri. "Connected Air Voids Content in Permeable Friction Course Mixtures". Journal of Testing and Evaluation. Vol. 37, pp. 254-263. 2009.

[6] L.A. Cooley Jr., J.W. Brumfield, R.B. Mallick, W.S. Mogawer, M. Partl, L.D. Poulikakos and G. Hicks. "Construction and Maintenance Practices for Permeable Friction Courses". NCHRP Report 640. Washington, D.C. 2009.

[7] V. Ranieri. "The Functional Design of Porous Friction Courses". TRB 86th Annual Meeting, Washington D.C., 2007.

[8] R.E.Y. Yeo, J. Favaloro and P. Mousley. "An Australian Perspective on the Functional Durability of Open Graded Asphalt Surfacing”. VicRoads-RMIT University. 2001. 
[9] T. Bennert, D. Hanson, A. Maher and N. Vitillo. "Influence of Pavement Surface Type on Tire/Pavement Generated Noise". Journal of Testing and Evaluation. Vol. 33, pp. 1-20. 2005.

[10] F.E. Pérez y C. Kraemer. "Empleo de Mezclas Bituminosas Porosas como Capa de Rodadura". Jornadas Nacionales sobre Firmes Flexibles. Barcelona, España. 1984.

[11] R.B. Mallick, P. Kandhal, L.A. Cooley (Jr.) and D.E. Watson. "Design, Construction, and Performance of New Generation OpenGraded Friction Courses". National Center for Asphalt Technology. Auburn, AL, USA. 2000.

[12] H. Khalid and F.E. Pérez. "Performance Assessment of Spanish and British Porous Asphalts". E \& FN Spon, p. 137. University of Leeds. Leeds, UK. 1996.

[13] M.S. Kabir, W. King Jr., C. Abadie, P. Icenogle and S.B. Cooper Jr. "Louisiana's Experience in Open-Graded Friction Course Mixtures". Transportation Research Board 91st Annual Meeting, Washington, D.C., USA. 2012.

[14] K.J. Kowalski, R.S. McDaniel, A. Shah and J. Olek. "Long-Term Monitoring of Noise and Frictional Properties of Three Pavements Dense-Graded Asphalt, Stone Matrix Asphalt, and Porous Friction Course". Transportation Research Record. Vol. 2127, pp. 12-19. 2009.

[15] C. Pagotto, M. Legret and P. Le Cloirec. "Comparison of the Hydraulic Behavior and the Quality of Highway Runoff Water According to the Type of Pavement". Water Research. Vol. 34, pp. 4446-4454. 2000.

[16] J. Van der Zwan, T. Goeman, H. Gruis, J. Swart and R. Oldenburger. "Porous Asphalt Wearing Courses in the Netherlands: State of the Art Review". Transportation Research Record. Vol. 1265, pp. 95-110. 1990.

[17] R. Elvik and P. Greibe. "Road Safety Effects of Porous Asphalt: a Systematic Review of Evaluation Studies". Accident Analysis and Prevention. Vol. 37, pp. 515-522. 2005.

[18] J.S. Chen, Y.C. Sun, M.C. Liao and C.C. Huang. "Effect of Binder Types on Engineering Properties and Performance of Porous Asphalt Concrete". Transportation Research Board 91st Annual Meeting, Washington D.C., 2012.
[19] Y. Yildirim, T. Dossey, K. Fults, M. Tahmoressi and M. Trevino. "Winter Maintenance Issues Associated with New Generation Open-Graded Friction Courses". Center for Transportation Research-The University of Texas at Austin. Austin, TX, USA. 2006.

[20] J.C. Nicholls and I.G. Carswell. "The Design of Porous Asphalt Mixtures to PerformanceRelated Criteria". Transport Research Laboratory (TRL) Report 497. Berkshire, UK. 2001

[21] H. Khalid and C.M. Walsh. "Design for Long Term Performance of Porous Asphalt". 2nd European Symposium, Performance and Durability of Bituminous Materials, pp. 211-226. Leeds, England. 1997.

[22] H. Bendtsen and B. Andersen. "Noise Reducing Pavements-State of the Art in Denmark". Report 141. Danish Road Institute. 2005.

[23] A.E. Alvarez, A. Epps Martin, C. Estakhri, J.W. Button, C. Glover and S.H. Jung. "Synthesis of Current Practice on the Design, Construction, and Maintenance of Porous Friction Courses". Report $\mathrm{N}^{\circ}$ FHWA/ TX-06/0-5262-1. Texas Transportation Institute-Texas A\&M University. College Station, TX, USA. 2006.

[24] P.S. Kandhal and R.B. Mallick. "Open-Graded Friction Course, State of the Practice". National Center for Asphalt Technology. Washington D.C., USA. 1998.

[25] R.W. Smith, J.M. Rice and S.R. Spelman. "Design of Open-Graded Asphalt Friction Courses". Report FHWA-RD-74-2. Federal Highway Administration. 1974.

[26] P. Kandhal and R.B. Mallick. "Design of New-Generation Open-Graded Friction Courses". NCAT Report N 99-3. National Center for Asphalt Technology-Auburn University. Auburn, Alabama. 1999.

[27] P.S. Kandhal. "Design, Construction, and Maintenance of Open-Graded Asphalt Friction Courses". Information series 115. National Asphalt Pavement Association. Lanham, MD. 2002.

[28] D.E. Watson, K.A. Moore, K. Williams and L.A. Cooley Jr. "Refinement of NewGeneration Open-Graded Friction Course Mix Design". Transportation Research Record. Vol. 1832, pp. 78-85. 2003. 
[29] A.E. Alvarez, A. Epps Martin and C. Estakhri. "Optimizing the Design of Permeable Friction Course Mixtures". Transportation Research Record. Vol. 2209, pp. 26-33. 2011.

[30] INVIAS. "Especificaciones Generales de Construcción de Carreteras y Normas de Ensayo Para Carreteras". Bogotá D.C., Colombia. 2007.

[31] L. Kline and B.J. Putman. "Comparison of Open Graded Friction Course (OGFC) Mix Design Procedures in the United States". Transportation Research Record 90th Annual Meeting. Washington D.C., USA. 2011.

[32] F.G. Praticò and A. Moro. "Measurement of Air Void Content in Hot Mix Asphalts: Method and Core Diameter Dependence". Construction and Building Materials. Vol. 26, Issue 1, pp. 344-349. 2012.

[33] M.S. Buchanan and T.D. White. "Hot Mix Asphalt Mix Design Evaluation Using the Corelok Vacuum-Sealing Device". Journal of Materials in Civil Engineering. Vol. 17, pp. 137-142. 2005.

[34] A.E. Alvarez, A. Epps Martin, C. Estakhri and R. Izzo. "Determination of Volumetric Properties for Permeable Friction Course Mixtures". Journal of Testing and Evaluation. Vol. 37, pp. 1-10. 2009.

[35] InstroTek®. “CoreLok® Operator's Guide. Version 20". InstroTek Inc., Raleigh, NC, 2003. 20.

[36] D.E. Watson, L.A. Cooley Jr., K.A. Moore and K. Williams. "Laboratory Performance Testing of Open-Graded Friction Course Mixtures". Transportation Research Record. Vol. 1891, pp. 40-47. 2004.

[37] L.K. Crouch, D. Badoe, M. Cates, T.A. Borden, A. Copeland, C.T. Walker, T. Dunn, R. Maxwell and W. Goodwin. "Bulk Specific Gravity of Compacted Bituminous Mixtures: Finding a More Widely Applicable Method". Publication TNSPR RES 1153. Tennessee Technological University. Cookeville, TN, USA. 2003.

[38] C.B. Nielsen. "Durability of Porous AsphaltInternational Experience". Technical Note 41. Danish Road Institute (DRI). Copenhagen, Denmark. 2006.

[39] S.N. Suresha, G. Varghese and A.U.R. Shankar. "A Comparative Study on Properties of Porous Friction Course Mixes with Neat Bitumen and Modified Binders". Construction and Building Materials. Vol. 23, pp. 1211-1217. 2009.

[40] F.E. Pérez and J. Gordillo. "Optimization of Porous Mixes Through the Use of Special Binders". Transportation Research Record. Vol. 1265, pp. 59-68. 1990.

[41] TxDOT. "Standard Specifications for Construction and Maintenance of Highways, Streets, and Bridges". Austin, TX, USA. 2004.

[42] M. Ameri and M.A. Esfahani. "Evaluation and Performance of Hydrated Lime and Limestone Powder in Porous Asphalt". Road Materials and Pavement Design. Vol. 9, pp. 651-664. 2008.

[43] Q. Lu and J.T. Harvey. "Laboratory Evaluation of Open-Graded Asphalt Mixes with Small Aggregates and Various Binders and Additives". Transportation Research Board 90th Annual Meeting. Washington D.C., USA, pp. 1-18. 2011.

[44] ASTM International. "ASTM D 706404: Standard Practice for Open-Graded Friction Course (OGFC) Mix Design". ASTM International, pp. 937-943. West Conshochocken, PA, USA. 2006.

[45] L.D. Poulikakos, S. Takahashi and M.N. Partl. "A Comparison of Swiss and Japanese Porous Asphalt Through Various Mechanical Tests". 3rd Swiss Transport Research Conference, Monte Verità/Ascona, pp. 1-12. 2003.

[46] British Standards Institute (BSI). "Coated Macadam (Asphalt Concrete) for Roads and Other Paved Areas-Part 1: Specification for Constituent Materials and for Mixtures. BS 4987-1:2005”. 2005.

[47] A.E. Alvarez, E. Ovalles and A. Epps Martin. "Comparison of Asphalt Rubber-Aggregate and Polymer Modified Asphalt-Aggregate Systems in Terms of Surface Free Energy and Energy Indices". Construction and Building Materials. Vol. 35, pp. 385-392. 2012.

[48] M.N. Partl, E. Pasquini, F. Canestrari and A. Virgili. "Analysis of Water and Thermal Sensitivity of Open Graded Asphalt Rubber Mixtures". Construction and Building Materials. Vol. 24, pp. 283-291. 2010.

[49] S. Caro and A.E. Alvarez. "Evaluación de la Susceptibilidad al Daño por Humedad de Mezclas Asfálticas Empleando Propiedades Termodinámicas". Revista Facultad de 
Ingeniería. Universidad de Antioquia. Vol. 58, pp. 95-104. 2011.

[50] D.E. Watson, E. Masad, K.A. Moore, K. Williams and L.A. Cooley Jr. "Verification of Voids in Coarse Aggregate Testing, Determining Stone-on-Stone Contact of Hot-Mix Asphalt Mixtures". Transportation Research Record. Vol. 1891, pp. 182-190. 2004.

[51] A.E. Alvarez, E. Mahmoud, A. Epps Martin, E. Masad and C. Estakhri. "Stone-on-Stone Contact of Permeable Friction Course Mixtures". Journal of Materials in Civil Engineering, ASCE. Vol. 22, pp. 1129-1138. 2010.

[52] S.N. Suresha, G. Varghese and A.U. Ravi Shankar. "Effect of Aggregate Gradations on Properties of Porous Friction Course Mixes". Materials and Structures. Vol. 43, pp. 789-801. 2010.

[53] C. Estakhri, T. Scullion and X. Hu. "Design and Performance Evaluation of a Fine-Graded Permeable Friction Course". Transportation Research Board 91st Annual Meeting, pp. 1-15. Washington, D.C., USA. 2012.

[54] F.E. Pérez and M.A. Calzada. "Analysis and Evaluation of the Performance of Porous Asphalt: The Spanish Experience". First International Symposium on Surface Characteristics. State College, PA, USA. 1990.

[55] A.E. Alvarez, E. Ovalles and S. Caro. "Assessment of the Effect of Mineral Filler on Asphalt-Aggregate Interfaces Based on Thermodynamic Properties". Construction and Building Materials. Vol. 28, pp. 599-606. 2012.

[56] A.E. Alvarez, A. Epps Martin and C. Estakhri. "A Review of Mix Design and Evaluation Research for Permeable Friction Course Mixtures". Construction and Building Materials. Vol. 25, pp. 1159-1166. 2011.

F.E. Pérez, C. Kraemer and A. Lacleta. "Enrobés Drainants. Etude de Leurs Caracteristiques en Laboratoire et Construction des Premiers Tronçons d'essais Espagnols". Eurobitume Symposium, Cannes. 1981.

[58] Centro de estudios y experimentación de obras públicas (CEDEX). "Spanish standard NLT-352/86 - Caracterización de las Mezclas Bituminosas Abiertas por Medio del Ensayo
Cántabro de Pérdida por Desgaste”. Madrid, España. 1986.

[59] F.E. Pérez. "Dosificación de Mezclas Porosas. Ensayo Cántabro”. Rutas, pp. 44-51. 1990.

[60] T. Kuennen. "Unraveling the Mystery of Asphalt Raveling". Better Roads. Vol. 77 $\mathrm{N}^{\circ}$ 4, pp. 50-58. April, 2007.

[61] A.E. Alvarez, A. Epps Martin and C. Estakhri. "Effects of Densification on Permeable Friction Course Mixtures". Journal of Testing and Evaluation. Vol. 37, pp. 11-20. 2009.

[62] R.Y. Kim. "Modeling of Asphalt Concrete". McGraw-Hill. New York, USA. 2009.

[63] A. Bhasin, J. Howson, E. Masad, D.N. Little and R.L. Lytton. "Effect of Modification Processes on Bond Energy of Asphalt Binders". Transportation Research Board 86th Annual Meeting. Washington D.C., USA. 2007.

[64] L.T. Mo, S.P. Wu, M. Huurman, A.A.A. Molenaar and T.W. Cao. "Damage Accumulation Model for Monotonic and Dynamic Shear Fracture of Asphalt-Stone Adhesion". Theoretical and Applied Fracture Mechanics. Vol. 46, pp. 140-147. 2006.

[65] A.E. Alvarez, E. Ovalles and A. Epps Martin. "Comparison of Asphalt Rubber-Aggregate and Polymer Modified Asphalt-Aggregate Systems in Terms of Surface Free Energy and Energy Indices". Construction and Building Materials. Vol. 35, pp. 385-392. 2012.

[66] CEDEX. "Spanish Standard NLT-362/92: Efecto del Agua Sobre la Cohesión de Mezclas Bituminosas de Granulometría Abierta, Mediante el Ensayo Cántabro de Pérdida por Desgaste". Madrid, España. 1992.

[67] O.J. Reyes-Ortiz and J.F. Camacho. "Efecto de la Radiación Ultravioleta en las Propiedades Mecánicas y Dinámicas de una Mezcla Asfáltica”. Ingeniería e Investigación. Vol. 28, pp. 22-27. 2008.

[68] H. Wang, L. Liu and L. Sun. "Characterization of OGFC Mixtures Containing Nano-scale Lignin Fibers". Transportation Research Board 91st Annual Meeting. Washington D.C., USA. 2012.

[69] L.A. Cooley (Jr.), E.R. Brown and D.E. Watson. "Evaluation of OGFC Mixtures Containing Cellulose Fibers". NCAT Report 00-05. National Center for Asphalt TechnologyAuburn University. Auburn, AL, USA. 2000. 
[70] X. Vargas, N. Afanasjeva, M. Alvarez, P. Marchal and L. Choplin. "Evolución del Comportamiento Viscoelástico del Asfalto Inducida Bajo Termo-Oxidación in Situ en un Reo-Reactor". DYNA. Vol. 155, pp. 191198. 2008.

[71] X. Vargas and F. Reyes. "Asphalt's Aging Phenomenon". Ingeniería e Investigación. Vol. 30, pp. 27-44. 2010.

[72] Instituto Nacional de Vías. "Especificaciones Generales de Construcción de Carreteras y Normas de Ensayo Para Carreteras". Bogotá D.C., Colombia. 2007.

[73] W. Shao-peng, L. Gang, M. Lian-tong, C. Zheng and Y. Qun-shan. "Effect of Fiber Types on Relevant Properties of Porous Asphalt". Transactions of Nonferrous Metals Society of China. Vol. 16, pp. 791-795. 2006.

[74] H.F. Hassan and K.S. Al-Jabri. "Effect of Organic Fibers on Open-Graded Friction Course Mixture Properties". The International Journal of Pavement Engineering. Vol. 6, pp. 67-75. 2005.

[75] J.E. Wurst. "Evaluation of Warm Mix Open Graded Friction Course Mixtures". Thesis, Clemson University. 2011.

[76] C. Estakhri, A.E. Alvarez and A. Epps Martin. "Guidelines on Construction and Maintenance of Porous Friction Courses in Texas". Report N ${ }^{\circ}$ FHWA/TX-08/0-5262-2. Texas Transportation Institute-Texas A\&M University. College Station, TX, USA. 2008.

[77] P.S. Kandal and I.J. Rickards. "Premature Failure of Asphalt Overlays from Stripping: Case Histories". NCAT Report 01-01. National Center for Asphalt Technology (NCAT)-Auburn University. Auburn, AL, USA. 2001.

[78] G. Huber. "Performance Survey on OpenGraded Friction Course Mixes. Synthesis of Highway Practice 284". Transportation Research Board, National Research Council. Washington D.C., USA. 2000.

[79] A.E. Alvarez, A. Epps Martin and C. Estakhri. "Drainability of Permeable Friction Course Mixtures". Journal of Materials in Civil Engineering, ASCE. Vol. 22, pp. 556-564. 2010.

[80] Centro de estudios y experimentación de obras públicas (CEDEX). "Spanish standard NLT-327/88: Permeabilidad in situ de pavimentos drenantes con el permeámetro LCS”. Madrid, España. 1988.

[81] A.E. Alvarez, A. Epps Martin and C. Estakhri. "Internal Structure of Compacted Permeable Friction Course Mixtures". Construction and Building Materials. Vol. 24, pp. 1027-1035. 2010.

[82] Federal Highway Administration (FHWA). "Open Graded Friction Course FHWA Mix Design Method. Technical Advisory T5040.31". FHWA-Department of Transportation. Washington D.C., USA. 1990.

[83] D. Rogge and E.A. Hunt. "Development of Maintenance Practices for Oregon F-Mix". Interim Report SPR 371. Oregon Department of Transportation. Salem, OR, USA. 1999.

[84] A. Wimsatt and T. Scullion. "Selecting Rehabilitation Strategies for Flexible Pavements in Texas". Transportation Research Board 82nd Annual Meeting. Washington D.C., USA. 2003.

[85] C. Bredahl. "Construction of Two-Layer Porous Pavements". European Experience Quiet Asphalt 2005 Symposium. 2005.

[86] U. Sandberg and Y. Masuyama. "Japanese Machines for Laying and Cleaning DoubleLayer Porous Asphalt-Observations from a Study Tour". Direction of RijkswaterstaatDWW, Co-Sponsored by Chalmers University of Technology DWW/IPG. 2005.

[87] V. Ranieri, P. Colonna, J.J. Sansalone and A. Sciddurlo. "The Measurement of Hydraulic Conductivity in Porous Mixes". Transportation Research Board 91st Annual Meeting. Washington, D.C., USA. 2012.

[88] F.E. Pérez. "Permeametro LCS". Universidad de Cantabria. Santander, España. 1985.

[89] AENOR. "Standard UNI EN 12697-19. Metodi di Prova per Conglomerati Bituminosi a Caldo. Miscele Bituminose. Parte 19: Permeabilità del Provino". ENTE 534 NAZIONALE DI UNIFICAZIONE. Milano, Italia. 2004.

[90] U. Sandberg and G. Descornet. "Road Surface Influence on Tire/Road Noise". International Conference on Noise Control Engineering. Miami, USA. 1980.

[91] G. Descornet. "Propietés Acoustiques". Journée Sur Enrobés Drainants. Centre de Recherches Routières. Bruxelles, Bélgica. 1988. 
[92] F.E. Pérez, M. Majó, F. Armengol y C. Sumpsi. "Efecto de las Mezclas Porosas sobre el Ruido de Rodadura". European Conference on Porous Asphalt. Madrid, España. 1997.

[93] D.I. Hanson and R.S. James. "Colorado DOT Tire/Pavement Noise Study". Report $\mathrm{N}^{\circ}$ CDOT-DTD-R-2004-5. National Center for Asphalt Technology, Auburn University. Auburn, AL, USA. 2004.

[94] K.-W. Liu, A.E. Alvarez, A. Epps Martin, T. Dossey, A. Smit and C. Estakhri. "Synthesis of Current Research on Permeable Friction Courses: Performance, Design, Construction, and Maintenance". Report $\mathrm{N}^{\circ}$ FHWA/
TX-10/0-5836-1. Texas Transportation Institute-Texas A\&M University. College Station, TX, USA. 2010.

[95] M. Trevino and T. Dossey. "A Research Plan for Measuring Noise Levels in Highway Pavements in Texas". Report $\mathrm{N}^{\circ}$ 0-5185. Center for Transportation Research, University of Texas at Austin. Austin, TX, USA. 2006.

[96] B. van Haaster, E. Worrell, J. Fortuin and W. van Vliet. "Potential Energy Saving of Reducing Rolling Resistance of Dutch Road Pavements". Journal of Materials in Civil Engineering. Vol. 26. URL: http:// ascelibrary.org/doi/abs/10.1061/(ASCE) MT.1943-5533.0000999. 2013. 